\title{
Designing the Future of The Territory Through Secondary Schools: The Case of Gazteen Gipuzkoa
}

\author{
Igone Guerra \\ University of the Basque Country
}

\author{
Xabier Barandiaran \\ University of Deusto
}

This paper is structured around the experience of the Gazteen Gipuzkoa project within the framework of the Etorkizuna Eraikiz initiative. The project was carried out throughout 2018 in 25 schools of Gipuzkoa with the aim of promoting a culture of active participation among youth in the political decision making process. The case shown is a pilot project that seeks to give a voice and involve youth in the design of the territory's challenges. Young people should be the actors of the future and therefore should have a leading role in its definition.

\section{INTRODUCTION}

This document is structured around the experience of the Gazteen Gipuzkoa project within the framework of the Etorkizuna Eraikiz with young people (Building the Future) initiative, which has been developed throughout 2018 in 25 schools of Gipuzkoa. The aim of the project was to promote a culture of active participation among youth in the political decision making process, mainly in those issues that may affect them.

The aim of this text is not to validate or criticize the experience itself because it is too premature to do so. Therefore, what the authors want to show with this paper is the learning experience obtained through this innovative initiative.

This document is divided into four sections. Firstly, the framework in which the project takes place in Gipuzkoa (one of the three provinces of the Basque Country) is described. In this section, the main features of a collaborative model of governance, in which citizen participation is one of its central tenets, are also outlined.

Secondly, the role of the school in the promotion of values related to democracy is analysed, outlining a general description of the main notions concerning the concepts of school, society and democracy.

Thirdly, the Gazteen Gipuzkoa project, approved in the framework of the Etorkizuna Eraikiz initiative with the youth, will be presented. In this section, both, the design and methodology of the project will be explained. At the same time, it will describe the development of the process of the project and some reflections and lessons learned from the experience will be presented. 
Finally, in the fourth section some general conclusions will be presented. This section will be completed with the definition of the benefits obtained from the implementation of the project as well as the future steps to be developed after its implementation.

\section{ETORKIZUNA ERAIKIZ. A COLLABORATIVE MODEL OF GOVERNANCE FOR GIPUZKOA}

Currently, societies are undergoing great social, economic, cultural and political transformations. On the one hand, these serious global problems have blurred the institutional responsibilities required to face them. This confirms the need to seek solutions in a collaborative way, and overcome political, social and cultural barriers. Governments start to recognize that they cannot meet these global challenges alone. Thus, they have started to design governance processes based on cooperation and collaboration between different agents. On the other hand, the crisis that Western countries suffered in 2007 exposed a great deficiency in the democratic system of our societies. A deficiency that has led to a great distrust of the citizenship in the political and institutional system. This idea is defended by the International Institute for Democracy and Electoral Assistance IDEA 2017 in The Global State of Democracy. Exploring Democracy's Resilience where it is stated that "there is evidence of a growing disconnect between politicians and the electorate. Transnational challenges related to inequality, migration and globalization are complex problems that challenge democratic institutions to respond effectively to public concerns, causing a decline in trust and legitimacy in democratic governance" (IDEA, 2017, p. xiii).

According to the Association des États Généraux des Étudiants de L'Europe AEGEE “the dissatisfaction with politicians, together with the lack of trust towards the governments, is seen as the strongest barrier to participation that young people face; around $40 \%$ of the respondents expressed that this is their main obstacle to participation in democracy" (Position Paper on Youth Rights AEGEE, 2013).

Politicians are seen as "the outsiders" who are far away from the real problems and needs of the society.

By the same token, there are several studies that affirm that young people are, more and more, moving apart themselves from institutional politics. The way of understanding the political spheres does not remain the same as it was in the traditional way. The mode of living politics among young people is becoming "increasingly diverse, non-exclusive and incompatible with traditional modes of engagement" (Kopert, Wamerdam, \& van Brakel, 6 November 2013).

However, voting is not the unique way of participation in the Democratic sphere. There are multiple activities in which young people can participate and involve in activities to design the future of the societies they live in. Regarding democratic participation for IDEA "participation is about having the right, and the possibility the opportunity and the support to participate in and influence decisions and involve in actions and activities to help to build a better society" (IDEA, 2017).

Thus, the complexity of these problems is demanding a new approach, different to the one traditionally used. It is in this context that the commitment to develop a new model of governance based on openness, collaboration and transparency becomes stronger as it is stated by numerous scholars such as Emerson, Nabatchi, \& Balogh, 2011; Lathrop \& Luma, 2010; Sorensen \& Torfing, 2012, (Irastorza, Garcia, \& Satrustegui, 2017).

New models of governance in which the system of relations between the different actors of the territory has to change, as well as the role of citizenship in the decision-making process. And this is because it is now the time in which the involvement of citizenship in the definition of public policies is gathering momentum.

The Provincial Council of Gipuzkoa, that is the political institution in charge for defining public policies in the province of Gipuzkoa (The Basque Country), aware of this new reality, launched in 2016 the Etorkizuna Eraikiz initiative (Building the future, in the Basque language). With this initiative, the institution sought to establish a new model of governance that is more open and collaborative to define in cooperation with the different actors of the territory (academia, private sector, NGO's, citizens, and so on) the challenges of Gipuzkoa for 2026. 
For Etorkizuna Eraikiz, collaborative deliberation is key to meeting competitiveness, social cohesion and the welfare of the territory. Means of collaboration that deploy from the creation of private - public alliances and the promotion of social participation, both through the organized society as well as the citizenry itself.

But the future is young. Therefore, it is mandatory that young people participate in the definition of the future of the territory, they have to be the main players of the building process to create the future society. Young people have important opinions, but these opinions sometimes are unknown. From Etorkizuna Eraikiz, giving space to the youth and, at the same time, putting into practice more active listening towards all the ideas, reflections, solutions and proposals that they can offer are two strategies to return young people to democratic life and to bridge the gap between the young people and institutional strengthening.

\title{
THE ROLE OF SCHOOL IN EDUCATION FOR DEMOCRACY
}

The United Nations system, since the Universal Declaration of Human Rights (1948), made clear the important role that education plays in the formation of citizens for democracy. This definition has been further strengthened and complemented through the conventions, treaties and declarations that the different agencies of the United Nations system have promoted, highlighting, among others, the adoption of the Convention on the Rights of the Child (1989), which in its Article 12 establishes participation as a fundamental right. Through active participation, young people are empowered and have a vital role in, both, their personal development as well as in the development of their communities. Children and adolescents have to be seen as active members of the community in which they live with full right not just to participate but also to be part of the decision making process. This is a reality that has to be learnt from school (UNICEF, s.f.).

The school is highlighted as a social space, of transmission of particular social learning. A space where students are trained in the importance of their participation in political decision making and the implications of democratic decision making. Citizenship implies collaboration and participation.

Supporting this idea, the European Youth Forum identifies the need to extend citizenship education beyond the school curriculum to provide students with practical opportunities to apply citizenship education in their school and community activities. In other words, a problem-based learning approach must be adopted thereby strengthening the bonds within the community.

One of the functions of the school is, among others, education for democracy, and refers to the development of skills and abilities for a social coexistence in solidarity, participation and respect, among other values. This is a critical function for developing self-awareness and social responsibility, given that we welcome students as supportive and critical, in school and in society.

Acting as models of democratic principles in action, the schools help students understand the nature of citizenship and teach them the knowledge and skills necessary to maintaining a democracy.

\section{GAZTEEN GIPUZKOA- YOUNG PARTICIPATION IN THE ETORKIZUNA ERAIKIZ INITIATIVE: DEFINING THE CHALLENGES OF GIPUZKOA}

\author{
"More projects like this have to be promoted because we are the Future". \\ A participant's opinion.
}

Within the framework of Etorkizuna Eraikiz and responding to its founding principles, young people are considered as key agents of change. Having the participation of youth in the decision-making processes strengthens the democratic system and the development and progress of societies (International Institute for State of Democracy and Elections, 2017).

The recognition of the school as a space for socialization and training in citizenship for democracy is promoted by the Etorkizuna Eraikiz initiative. Specifically, this understanding of the importance of the 
school in boosting democratic values is reflected in the regulatory basis of the 2018 Call for Innovative Projects. This document establishes one of the categories eligible for subsidy, that is:

"promoting the participation of people of school age, and in general, of young people in the reflection and collective construction that Etorkizuna Eraikiz represents" (Official Gazzette of Gipuzkoa, 2018, p.2).

Moreover, the University of the Basque Country identified one opportunity to embed this project with the key action 3 of the Erasmus Plus program entitled Structured Dialogues. Concerning the latter, its aim is to promote democratic values in youth through their participation in the decision making process. Taking into account that the goals of both projects were the same, it was decided to make a joint effort in developing a unique strategy to enhance democratic values in young people.

Thus, merging these two programs, as well as with the aim of strengthening participation, Gazteen Gipuzkoa project was approved in 2018 within the framework of the third call for innovation projects of the Etorkizuna Eraikiz initiative. The purpose of the project was to develop skills for citizenship inside the school, and, thus, promote the definition of current challenges of the territory from the youth's perspective.

In the following lines, we will explore different aspects of the design, methodology and development of the project.

\section{The Design of "Gazteen Gipuzkoa- Etorkizuna Eraikiz with Young people"}

The Provincial Council of Gipuzkoa, the research group of the University of the Basque Country (UPV/EHU), Sinnergiak Social Innovation and the Arizmendi educational cooperative worked together on the Gazteen Gipuzkoa-Etorkizuna Eraikiz project with young people.

The main objective of the project is to bring young people closer to both, politics as well as democracy, facilitating the much-needed transformation of politics. More specifically, the project was expected to offer young people a space to contribute with their ideas to the construction of the Etorkizuna Eraikiz initiative. And therefore, to collaboratively design the Gipuzkoa of the future through a scientific approach by helping design the challenges of the territory and to create solutions according to reality.

In addition to this, the project included other objectives related to the development of skills in young people, such as communicative skills (written, oral and digital): functional skills, critical thinking and the capacity for reflection; as well as technical skills, such as "living together" skills and other "life-skills".

The projects were aimed at students of secondary schools and high schools from the following types of schools: public, "ikastola" (a Basque type of school) and semi-private schools in Gipuzkoa.

\section{Methodological Approach}

The project is divided into three phases:

Phase I Awareness. A first presentation meeting was held. This meeting was organized by the Provincial Council of Gipuzkoa and developed in the "Foral Palace". Subsequently, 5 meetings were held to present the project with the participation of students and teachers from the schools interested in being part of the project. In all these meetings, a total of 454 young people belonging to 25 schools in the territory took part.

Phase II. Analysis of the challenges and preparation of the proposals. In order to carry out each project, each school organized four sessions in which the students could have the opportunity to develop different skills, such as:

- Identification of the challenge or challenges. Analysis of the context, identification of the challenges and solutions, reflections, analysis of the motivation for research, definition of tasks and teamwork

- Team building. Collecting data and teamwork to take advantage of the skills and competencies of each team member. 
- Decision making about the challenges and the solutions. Definition of the methodology of the project and the final type of work that would be shown and as well as, evaluation of the work.

- Execution. Carrying out of the work to be presented.

Phase III. Exhibition of the works. Once the previous phase has been fulfilled, 8 meetings to present the works were organised in the Etorkizuna Eraikiz Gunea (a laboratory for designing public policies) in which around 500 students from 25 participating schools took part.

\section{Main Results}

High rate of participation of schools, teachers and the students. This is the first time in which a project of these characteristics has been developed in the territory. Although at the beginning of the project, it was very difficult to engage schools in it, all the participants have shown great commitment to the aim of the project. 25 schools, around 500 students and more than 50 teachers participated in the project. The participating schools responded to the following typology: 7 from the semi-private schools, 9 from public schools and 10 from the "ikastola" (the Basque typology of schools).

Diverse topics. Many issues were presented by the students but all of them reflected the main concerns of the territory about the future, with topics regarding sustainability, social and economic issues as well as cultural concerns. Thus, the works included topics such as: climate change, reduction of consumption of energy, treatment of waste, the future of the labour market, the ageing of society, gender issues (domestic violence), the future of education, the problem of substance abuse and the lack of housing, among others.

Diverse typology of works such as, the making of several short-films to highlight each topic; theatrical performance to illustrate concerns and propose solutions; and photo gallery presentation about the topics, and so on.

Commitment of the students to the democratic life. Students at the beginning of the project showed their dissatisfaction with the way in which democracy was being developed. Specifically, they showed their lack of trust in political institutions. The project has supported a new commitment from the students to the future of the territory. In their opinion, this project has been very challenging and has awoken their interest about participation in the future design of Gipuzkoa. Some values like freedom, justice, equality, tolerance, the respect for others' opinions, the value of the word among others have been strengthened by the project. All these values have been exhibited in all the works the students have developed.

In addition to this, the students had the chance to experiment with democracy. They were encouraged to define their own projects, from the selection of the topic to be investigated to the definition of the format in which the work would be presented. To do this, they had to reach a common understanding within the group, as well as developing learning modes for tolerance and coexistence.

Acquisition of skills. Thanks to the project the students had the opportunity to acquire skills such as:

- Research skills. The students were asked to identify a problem in their communities and to develop sound projects about causes, consequences and the proposal of solutions to tackle the problem. In order to fulfil a whole process of the research project, students had to learn how to identify the problem and the challenge, how to approach the community to apply research methodologies such as questioning and interviews, and finally how to develop critical thinking to select useful information for the project.

- Team building skills. In each participating schools the students were divided into smaller groups in order to develop micro-projects about a topic. The students through this experience could learn how to deal with differences, how to make the most of each one (identifying the strengthen of each member of the team) and how to develop mechanisms of tolerance and trust.

- Communication skills. The Common European Framework of Reference for Languages speaks of communicative competences of the language, which include linguistic, 
sociolinguistic and pragmatic competences, and which -in turn- are integrated into the general competences of the individual, which are the following: knowledge ( general knowledge of the world, sociocultural knowledge, intercultural awareness); know-how (skills and abilities); know-how (existential competence: relative to attitudes, motivations, values, beliefs, and so on; and the knowledge to learn (Naval, 1998).

Within the project, the following communicative competences have been promoted: writing and digital skills. Regarding the results, it was noted that the activities within the classroom which promoted the development of communicative skills were oral presentations, collaborative learning and the preparation of essays.

Impact assessment. In the framework of the project, an evaluation assessment was applied in which 370 forms were collected. In addition to their reflections on the project, the students offered their opinions about how to improve the process of the project, obtaining interesting recommendations related mainly to the duration of the project, its presentation (regarding motivation to participate), the methodology and solutions to facilitate greater participation of young people in this kind of initiative. As can be observed in the following figure, the students were asked about 8 dimensions, these are: interest of the project, fulfilment of expectations, information offered, knowledge obtained, methodologies explained, strengths and weaknesses identified with regard to completing the works, the level of learning from experience, and recommendations for future editions.

\section{FIGURE 1 \\ DIMENSIONS EVALUATED BY STUDENTS PARTICIPATING IN GAZTEEN GIPUZKOA}

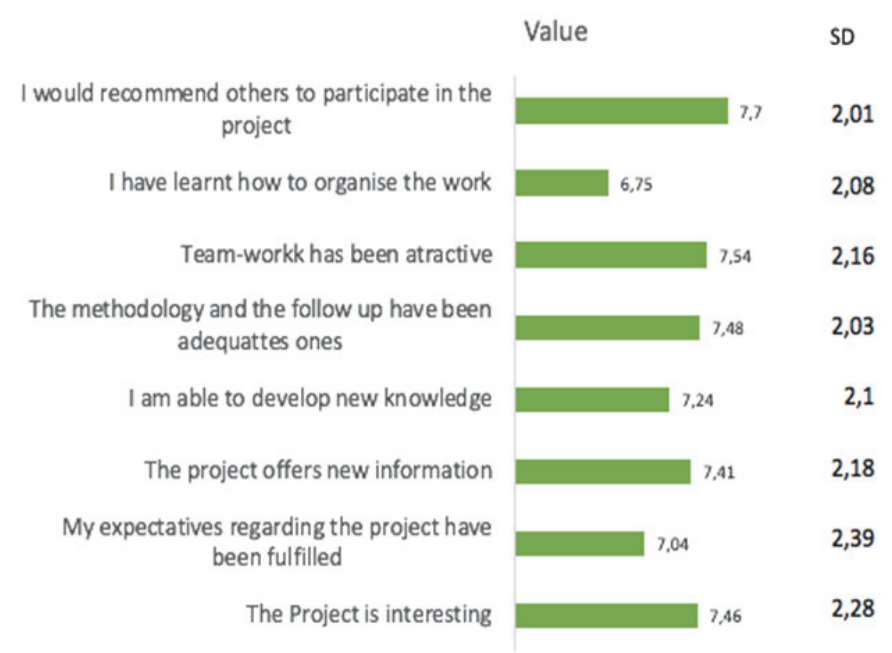

Source. Sinnergiak Social Innovation, 2018

From the students perspective, the experience has been very positive, they would recommend to others participation in future editions of this project, this statement was the most valued, achieving the highest grade with a score of 7.70 They also expressed that the project was very interesting and attractive. Students also gave a high grade for team work, emphasizing particularly both, the skills needed to organize the tasks and the motivation for the projects. Concerning low-scoring statements, students identified poor learning of statistical methods.

Dissemination of the Works. Once the students finished their works, they were presented to other students in public presentations. In this way, they had the opportunity to contrast and work with each other. These works led to great knowledge transfer as students learnt from each other and had the opportunity to discuss their findings and experiences with their fellow peers. The results of this project will be shown to other schools that have not participated in this edition but could be part of a future one. 


\section{CONCLUSIONS}

The voice of youth is rarely heard outside the classroom. Youth must have a space where they can debate, experiment and contrast ideas from critical reflection and the school represents the ideal place to transmit the true essence of the democratic system (Diputación Foral de Gipuzkoa, 2018). In this sense, the project has been an opportunity for students to work together, investigate, discuss, collect, reflect, classify and organize the knowledge obtained from the approach to the challenges of the territory and to present them in the community.

The students of Gipuzkoa have been the main actors of their process of learning. The teachers have been the mentors, but the students have defined their own way of learning, facing challenges, solving problems and fulfilling work with their friends. Listening and encouraging the expression of their student voices is important and essential given that they are the main actors and protagonists of this process and the quality of their school experiences is a key aspect of their integral formation. As it was stated by Dewey, the school must be a place to resolve practical problems through collective deliberation and rational discussion that result on the importance of building and defending own ideas, and developing the tolerance to the ideas of the others (Dewey, 1964)

Through the project, we have managed to give voice to one of the groups, young people, who are always outside the political decision making. The proposals of the young people will be presented in a second phase within the framework of General Assemblies of the territory of Gipuzkoa.

These students demonstrated a capacity to engage with the realities of their day-to-day life. First, they were able to identify a broad range of factors that had a negative impact on their life. They were also able to analyse the relationship between those factors and the concept of cause and effect. Finally, they demonstrated a capacity and a willingness to translate that analysis into practical action to improve their local environment. The extent to which these children felt empowered to make a difference to their own life is particularly valuable.

The project is still on an early stage to be able to asses that it is strengthening future participation in the democratic life, but what the project poses undoubtedly is an educative quality help students to be prepared for playing a full role in democratic institutions.

Education and democracy are therefore demanding challenges and responsibilities, a challenge and a sense of the meaning of life. 


\section{REFERENCES}

Dewey, J. (1964). Democracy and Education. An introduction to the Philosophy of Education. London: Ed. MacMillan Company.

Diputación Foral de Gipuzkoa. (2018). Bases reguladoras y convocatoria 2018 de las líneas de subvenciones del programa Etorkizuna Eraikiz GipuzkoaLab. Boletin Oficial de Gipuzkoa. Donostia-San Sebastian, Gipuzkoa, País Vasco: Diputación Foral de Gipuzkoa.

IDEA. (2017). The Global State of Democracy. Exploring Democracy's Resistance.

International Institute for State of Democracy and Elections. (2017). The Global State of Democracy, Exploring Democracy's Resilience.

Irastorza, X. B., Garcia, A. L., \& Satrustegui, A. U. (2017). La innovación Pública en Gipuzkoa: El caso Etorkizuna Eraikiz. VIII Congreso Internacional en Gobierno, Administración y Politicas Públicas. Madrid: GIGAPP.

Kopert, S., Wamerdam, S., \& van Brakel, R. (2013). Evaluation of the European Commission-European Youth Forum Operating Grant Agreements. Rotterdam: ECORYS.

Naval, C. (1998). Educar ciudadanos: La polémica liberal-comunitarista en educación. Pamplona, Navarra: EUNSA, Ediciones Universidad de Navarra.

Position Paper on Youth Rights AEGEE. (2013). AEGEE position paper. Obtenido de AEGEE Europe. Retrieved from https://www.aegee.org/position-paper-on-youth-rights/

UNICEF. (n.d.). UNICEF. Child rights convention. Retrieved from https://www.unicef.org/child-rightsconvention 